\title{
SALTWATER - FRESHWATER WETLAND ECOSYSTEM AND URBAN LAND USE CHANGE IN PORT HARCOURT METROPOLIS, NIGERIA
}

\author{
Wali, E. ${ }^{1}$, Phil-Eze, P.O. ${ }^{1}$, Nwankwoala, H.O. ${ }^{*}$ \\ ${ }^{1}$ Department of Geography, University of Nigeria, Nsukka \\ ${ }^{2}$ Department of Geology, University of Port Harcourt, Nigeria \\ *Corresponding Author Email: nwankwoala_ho@yahoo.com
}

This is an open access article distributed under the Creative Commons Attribution License, which permits unrestricted use, distribution, and reproduction in any medium, provided the original work is properly cited

\section{ARTICLE DETAILS}

\section{Article History:}

Received 12 November 2017 Accepted 12 December 2017 Available online 1 January 2018

\begin{abstract}
Urban development in wetland ecosystems for human settlement, transport networks, exploration /exploitation of natural resources, agriculture and industrial development is one of the biggest menace to wetland change and management. To estimate future urban expansion is very crucial for urban planners and environmental managers in fastest growing cities. This study aims to examine the saltwater/freshwater ecosystem and urban land use change in Port Harcourt metropolis, Nigeria. Sources of data for this study were acquired from a time series of landsat Thematic Mapper (TM) and Enhanced Thematic Mapper plus (ETM+) with Thermal Infrared Sensor (TIRS) images were used to derive land use and land cover maps of the Port-Harcourt metropolis. This study revealed that both freshwater wetland and saltwater wetlands ecosystem occupied $46.99 \%$ (18837.1 Ha) of the total classes. This may be the result of wetland being in an undisturbed nature without any conversion or alteration for use. The urban land use change of PortHarcourt metropolis had changed dramatically during the period of 29 years. The two wetlands (saltwater and freshwater wetland) sum up to a total of $40 \%$ (16497.5 Ha) which indicates that there is pressure on wetland use such as plant products harvested from fuel wood, human settlement, urban agriculture, sand dredging, sanitation, water pollution and industrial activities from oil companies within the metropolis. Efforts should be made to increase knowledge, sensitization, consultation, stakeholder's participation and awareness on the wetlands values and wise use economy through dissemination of information, using appropriate techniques and training of adequate staff as well as the need for sound wetland policies, laws and legislation for sustainable use, management and control in conservation of wetland.
\end{abstract}

\section{KEYWORDS}

Urban Land Use Change, Saltwater/Freshwater, Wetland Ecosystem, Wetland Management, Port Harcourt.

\section{INTRODUCTION}

In the context of Convention adopted by Ramsar, Convention (Article 1.1), wetlands are defined as areas of marsh, fen, peat land or water, whether natural or artificial, permanent or temporary, with water that is static or flowing, fresh, brackish or salt, including areas of marine water the depth of which at low tide does not exceed six meters [1,2]. In addition, the convention (Article 2.1) also provide that they may incorporate riparian and coastal zones adjacent to the wetlands, and islands or bodies of marine water deeper than six meters at low tide lying within the wetland $[1,2]$.

Wetland ecosystems are among the most important in the world, providing a diverse range of ecosystem services vital to human well-being [2,3-5]. They gave rise to the first modern global nature-conservation convention and remain the only single group of ecosystems with their own International Convention [6-8]. Urbanization is a major cause of loss of coastal wetlands.

Urbanization impacts wetlands in numerous direct and indirect ways. For example, construction reportedly impacts wetlands by causing direct habitat loss, suspended solids additions, hydrologic changes and altered water quality. Indirect impacts include changes in hydrology and sedimentations which substantially alter wetlands. It also exerts significant influences on the structure and function of coastal wetlands, mainly through modifying the hydrological and sedimentation regimes, and the dynamics of nutrients and chemical pollutants [9].

Wetland ecosystems are important natural habitat, which must be conserved $[10,11]$. They are associated with a diverse and complex array of direct and indirect uses. Direct uses include the use of the wetland for water supply and harvesting of wetland products such as fish and plants resources, while indirect benefits are derived from environmental functions such as flood water retention, ground water recharge/discharge, nutrient abatement etc. Human activities in the wetland themselves may be fairly related to alternations; they may also be caused by activities in the wetland watersheds and predominantly by agricultural ones i.e. crop and livestock's production [12]. Changes in wetland area may significantly affect the ecosystem processes and services.

Concern about changes in the size and quality of many of the world's wetlands ecosystem has been growing as more and more wetlands are being converted to agricultural or urban land use and as a result of natural factors like drought [13-15]. This study therefore aims at developing a spatial data base on land use and land cover change, with an emphasis on land use classes, assess the ecological and socio-economic effects of wetland use, to map and generate the inventory of wetlands within the Port-Harcourt metropolis between 1984 and 2013, and to explore the causes of degradation of the wetlands.

\section{THE STUDY AREA}

Geographically, the Port-Harcourt metropolis is positioned between Latitudes $4^{\circ} 45^{\prime} \mathrm{N}$, and $4^{\circ} 55^{\prime} \mathrm{N}$ and Longitudes $6^{\circ} 55^{\prime} \mathrm{E}$ and $7^{\circ} 05^{\prime} \mathrm{E}$. PortHarcourt metropolis is located at about $25 \mathrm{~km}$ from the Atlantic Ocean and it is situated between the Dockyard Creek/Bonny River and the Amadi Creek [16,17]. Port-Harcourt, originally known, as "Igwe-Ocha" was founded in 1913 by the British in an area traditionally inhabited by the Ikwerres. It was named after Lewis Viscount Harcourt, the then Secretary 
of State of Colonies. The main City of Port Harcourt is the Port-Harcourt City Local Government Area. It serves as the Headquarters of Rivers State [18]. Today, the Port-Harcourt metropolis is made up of two Local Government Areas, namely Port-Harcourt L.G.A. and Obio-Akpor LGA (Figure 1).

The Port-Harcourt metropolis features within a tropical monsoon climate of transitional zone of KoppenAf climatic types with prolonged and heavy rainy season and very short dry season months in the city. Only the months of December and January truly qualifies as dry season months in the city. The harmattan, which climatically influences many cities in West Africa, is less pronounced in Port-Harcourt. The heaviest precipitation in PortHarcourt occurs between March and October [17]. The mean annual rainfall is put at $2,000 \mathrm{~mm}[19]$. The Port-Harcourt metropolis usually has a temporary cessation of rain commonly known as "August Break" (a dry spell) that comes in between the middle of the rainy season. The area has an average monthly temperature above $27^{\circ} \mathrm{C}$ and there is adequate

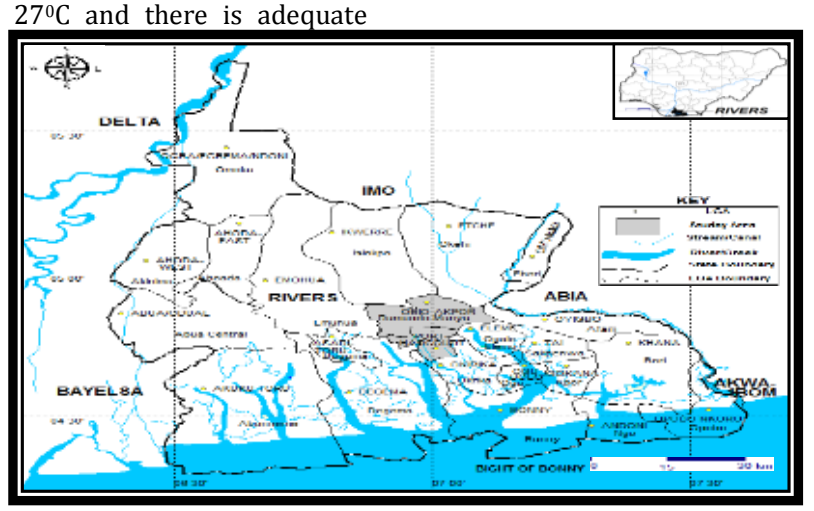

Figure 1: Map of Rivers State Showing Port Harcourt and Obio/Akpor L.GA

\section{METHOD OF STUDY}

\subsection{Data Acquisition and Sources}

Sources of data for this study were acquired from a time series of landsat Thematic Mapper (TM) and Enhanced Thematic Mapper plus (ETM+) with Thermal Infrared Sensor (TIRS) images were used to derive land use and land cover maps of the Port-Harcourt metropolis. The data set includes a notable period of four years for, 1984, 1999, 2003 and 2013 (Table 1). The raw satellite data were obtained from the archive of the United States Geological Survey and Earth Explorer. The maps were projected using moisture in virtually all the months.

The relief of the area is low-lying, and the rivers are influenced by tidal fluctuation. The Port-Harcourt metropolis lies at an average altitude of about $12 \mathrm{~m}$ above mean sea level. In terms of general surface features, the Port-Harcourt metropolis is very unique. The area falls within the coastal belt dominated by low-lying coastal plains which structurally belong to the sedimentary formation of the recent Niger Delta [20]. It consists mainly of muddy deposit pushed out of the River Niger into a relatively tide-less salt sea. The Port-Harcourt metropolis is drained by many rivers such as, Ntawogba, New Calaber, Amadi creek, Dockyard creek, Dick Fiberesima creek, Isaka River, Mini Apalugo, Elechi creek, Primose River, MgbuodohiaRiver,etc.

Table 1: Data Source (Source: USGS, 2014)

\begin{tabular}{|c|c|c|c|c|c|c|c|c|}
\hline S/N & $\begin{array}{l}\text { SATELITE/ } \\
\text { DATA } \\
\text { TYPE } \\
\end{array}$ & SENSOR & PATH/ROW & DATE & SACLE & BANDS & $\begin{array}{l}\text { CLOUD } \\
\text { COVER }\end{array}$ & SOURCE \\
\hline 1 & Landsat 5 & Thematic Mapper (TM) & $188 / 057$ & $13 / 12 / 84$ & $30 \mathrm{~m}$ & $\begin{array}{l}1,2,3,4,5,6 \\
\text { and } 7\end{array}$ & 0 & $\begin{array}{l}\text { Courtesy of the U.S. Geological Survey. } \\
\text { Earth Explorer. }\end{array}$ \\
\hline 2 & Landsat 7 & $\begin{array}{l}\text { Enhanced Thematic Mapper } \\
\text { plus (ETM+) }\end{array}$ & $188 / 057$ & $29 / 11 / 1999$ & $30 \mathrm{~m}$ & $\begin{array}{l}1,2,3,4,5,6 \\
\text { and } 7\end{array}$ & $10 \%$ & $\begin{array}{l}\text { Courtesy of the U.S. Geological Survey. } \\
\text { Earth Explorer. }\end{array}$ \\
\hline 3 & Land sat7 & $\begin{array}{l}\text { Enhanced Thematic Mapper } \\
\text { plus (ETM+) }\end{array}$ & $188 / 057$ & $08 / 01 / 2003$ & $30 \mathrm{~m}$ & $\begin{array}{l}1,2,3,4,5,6 \\
\text { and } 7\end{array}$ & 0 & $\begin{array}{l}\text { Courtesy of the U.S. Geological Survey. } \\
\text { Earth Explorer. }\end{array}$ \\
\hline 4 & Land Sat7 & $\begin{array}{l}\text { Enhanced thematic Mapper } \\
\text { plus (ETM+) }\end{array}$ & $188 / 057$ & $21 / 12 / 2013$ & $30 \mathrm{~m}$ & $\begin{array}{l}1,2,3,4,5,6 \\
\text { and } 7\end{array}$ & 0 & $\begin{array}{l}\text { Courtesy of the U.S. Geological Survey. } \\
\text { Earth Explorer. }\end{array}$ \\
\hline
\end{tabular}

\subsection{Geo- Referencing Properties of the Images}

The Geo-referencing properties of 1984, 1999, 2003 and 2013 made up of Universal Transverse Mercator (UTM) projection, and datum WGS 84, zone 32. Based on the prior knowledge of the study area for over 30 years and a brief ground-routing with additional information from previous research in the study area, a classification scheme was developed [21]. The classification scheme developed gives a rather broad classification where
Universal Transverse Mercator (UTM) and datum WGS 84 of zone 32. These data sets sensors have repeat cycles of 20 days, ground pixel dimension of $57 \times 79 \mathrm{~m}(\mathrm{TM}), 16$-bit pixel for values TIRS and the spectral range includes seven spectral bands in the visible/near infrared (VNIR)Bands 1, 2, 3 and 4), shortwave infrared (SWIR - Bands, 5 and 7) and thermal infrared TIR - Band 6) parts of the electromagnetic (EM) spectrum. The spectral resolution of Landsat TM and ETM+ $(30 \mathrm{~m})$ data makes it very useful for land use change and land cover classification and general mapping.

Table 2: Land Use/Land Cover Classification [21]

\begin{tabular}{|l|l|l|}
\hline S/N & $\begin{array}{l}\text { LEVEL 1, LAND USE /LAND COVER } \\
\text { CATEGORIES }\end{array}$ & LAND USE/LAND COVER DESCRIPTION \\
\hline 1 & FALLOW LAND & This includes farmland, sparse vegetation and thick vegetation. \\
\hline 2 & SALTWATER WETLAND & $\begin{array}{l}\text { Salt water ecosystem of tidal/sub tidal lands, salt water estuaries' habitats, and beach, flat or contiguous lowland subjected } \\
\text { to tidal action. }\end{array}$ \\
\hline 3 & BUILT UP AREA & $\begin{array}{l}\text { Urban area, industrial layout, bare soil, residential, commercial, educational, infrastructure, road network, pipeline, flow } \\
\text { station, oil and gas facilities, flow lines, open and cleaned areas. }\end{array}$ \\
\hline 4 & FRESHWATER WETLAND & These are fresh water ecosystem mainly swamps, marshes and bogs etc. \\
\hline
\end{tabular}


This involved identifying a set of sample locations and conducting field visit to the study site on Monday $22^{\text {nd }}$ June and Tuesday $7^{\text {th }}$ July 2015 to validate these locations. The land use and land cover found were compared to that which was mapped in the image for the same locations. Photographs and coordinates of the various land-use land-cover were obtained with a hand-held GPS.

\subsection{Saltwater Wetland Ecosystem}

The saltwater wetland is mainly salt-water ecosystems (Plates 1 - 3). They are primarily associated with floodplains of estuaries of large rivers and water courses [5, 22]. In the study conducted in Nigeria, some groups researchers identify two major types of wetlands in Nigeria; they are freshwater wetlands and saltwater wetlands [23]. Saltwater wetlands mean all tidal and sub-tidal lands, including all areas below any identifiable debris line left by tidal action; all areas with vegetation present that is tolerant of salt water and occurs primarily in salt water or estuarine habitat; and any swamp, marsh, bog, beach, flat or other contiguous lowland which is subject to tidal action.

The saltwater ecosystem wetland over the study years has the size shown in the results. Table 4 shows that the year 1984 recorded $6086.52 \mathrm{Ha}$ of land in size,1999 with $5190.23 \mathrm{Ha}, 2003$ with 5530.59Ha and in 2013 salt water wetland reduced to $5411.79 \mathrm{Ha}$ in size. From figure $2-5$, we can see the spatial distribution of wetlands in the Port-Harcourt metropolis in $1984,1999,2003$ and 2013 with the spatial extent of wetlands decrease between 1984, 1999, 2003 and 2013 in the study area as shown in figure 6-13.

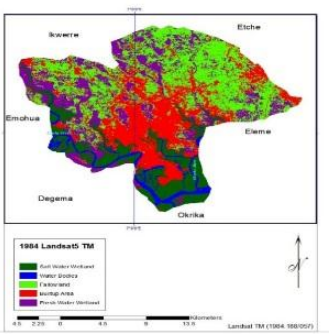

Figure 2: 1984 Landsat5 TM Image

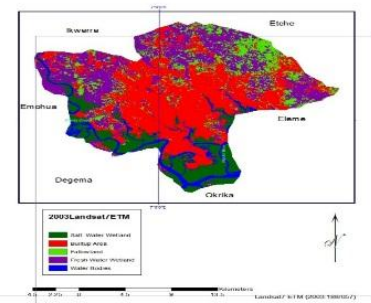

Figure 4: 2003 Landsat7 ETM Image Image

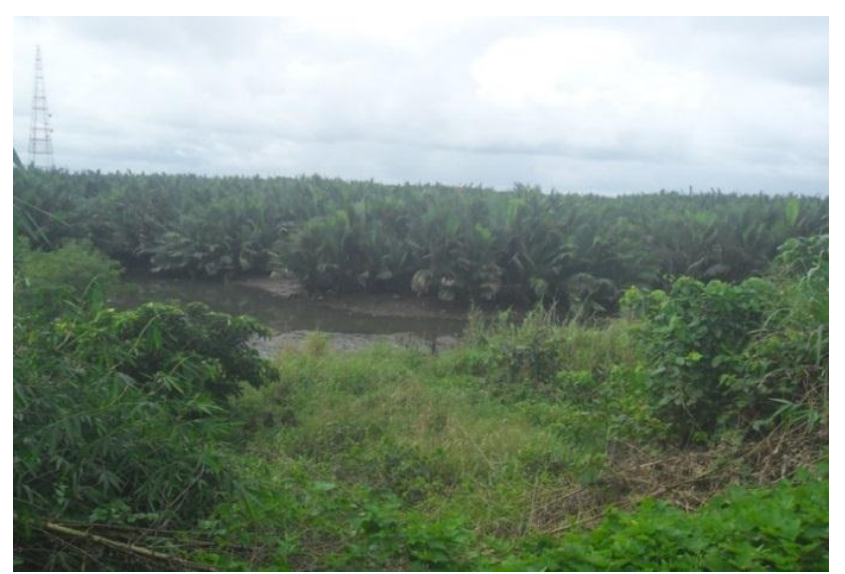

Hospital Board, Mile 1 Diobu, Port-Harcourt Management

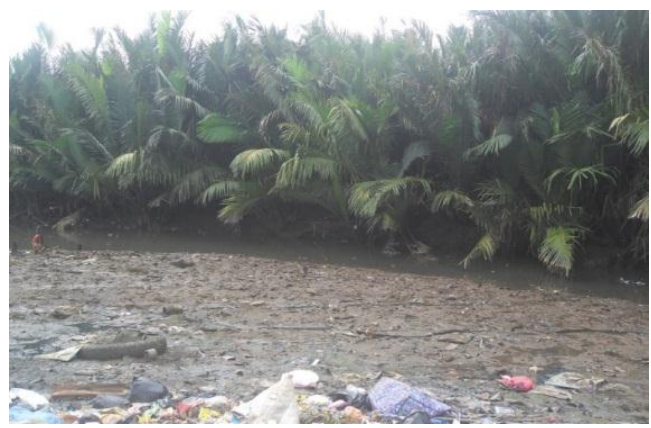

Plate 2: Saltwater wetland Ecosystem at Elechi Beach Mile 1 converted to dump site

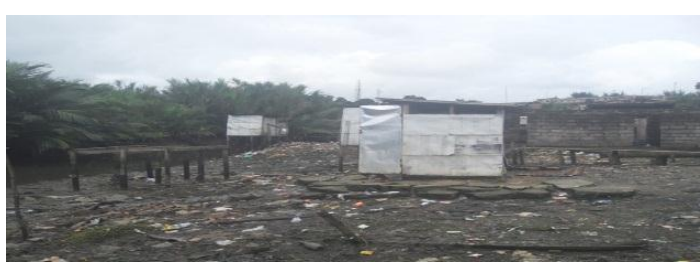

Plate 3: Saltwater wetland Ecosystem at Borikiri Area, Port-Harcourt

\subsection{Freshwater Wetland Ecosystem}

Freshwater wetlands are mainly fresh water ecosystems (Plates 4 - 6) They occur wherever ground water, surface spring, streams or run-off courses, saturated soils or frequent flooding creates temporary and/or permanent shallow water bodies. Freshwater wetlands include swamps, marshes, bogs and similar areas that are inundated or saturated by surface or groundwater at a frequency and for duration sufficient to support the ecosystem. The size of fresh water ecosystem from our review in table 3indicates that in the year 1984, wetland size was $12750.58 \mathrm{Ha}$, this increased to $12886.20 \mathrm{Ha}$ in 1999 , by 2003 it became $10966.91 \mathrm{Ha}$ and by 2013 the size was 9747.28 Ha of an aerial extent around the metropolis.

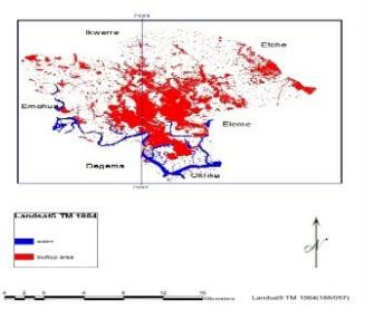

Figure 6: Built up Area as at 1984

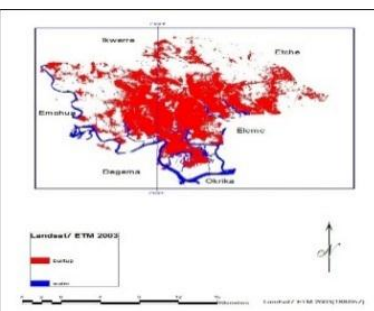

Figure 8: Built up Area as at 2003

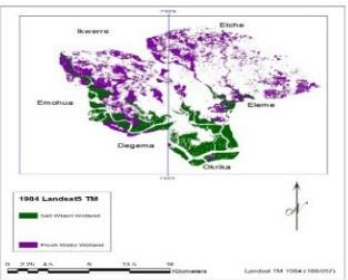

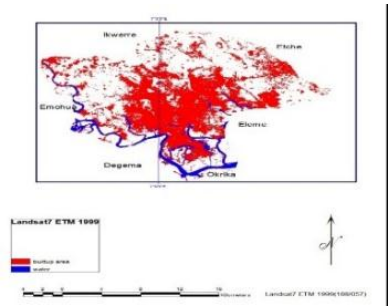

Figure 7: Built up Area as at 1999

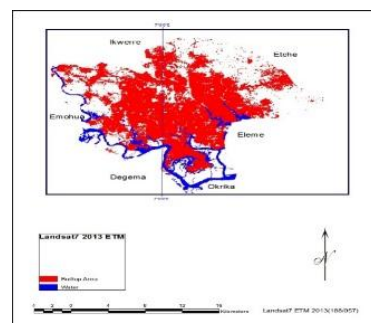

Figure 9: Built up area as at 201

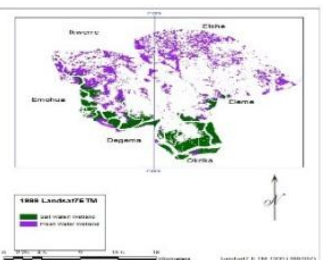

Plate 1: Saltwater wetland Ecosystem at low tide near Rivers State 
Figure 10: Wetland as at 1984

Figure 11: Wetland as at 1999

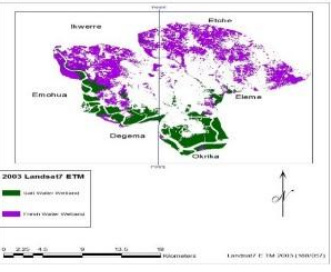

Figure 12: Wetland as at 2003

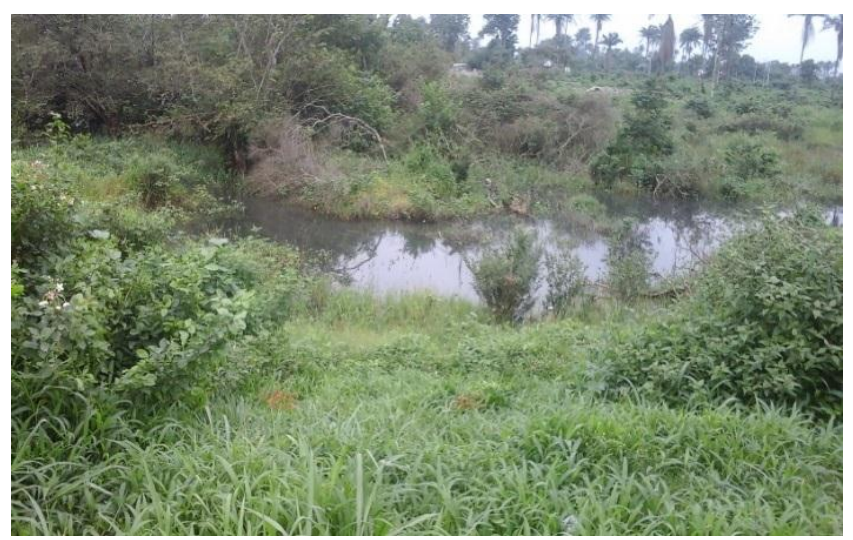

Plate 4: Freshwater Wetland experiencing transformed Seasonal high tide at Rukpokwu

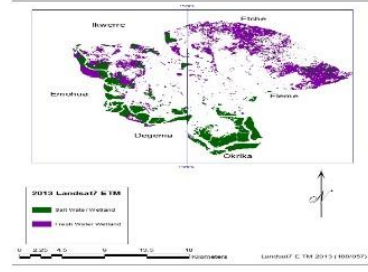

Figure 13: Wetland as at 2013

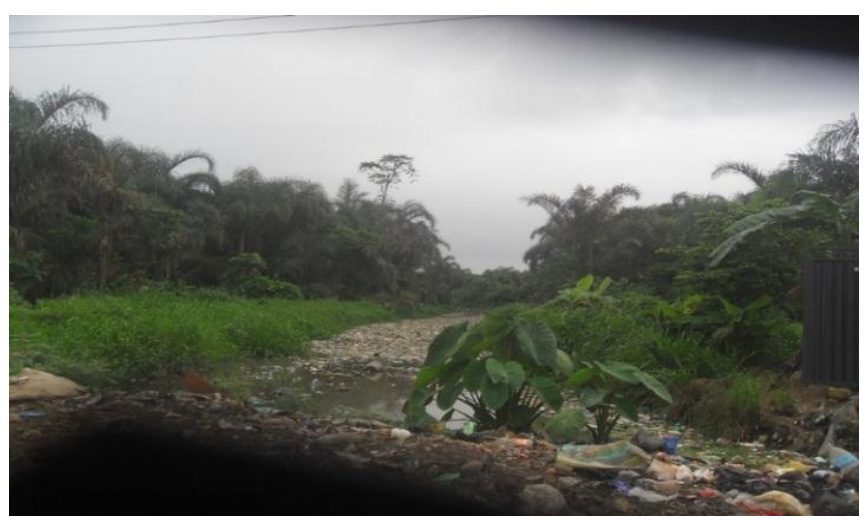

Plate 5: Freshwater Wetland being to dumpsite at Rumuolumini Community near Ignatius Ajuru University of Education, Port Harcourt

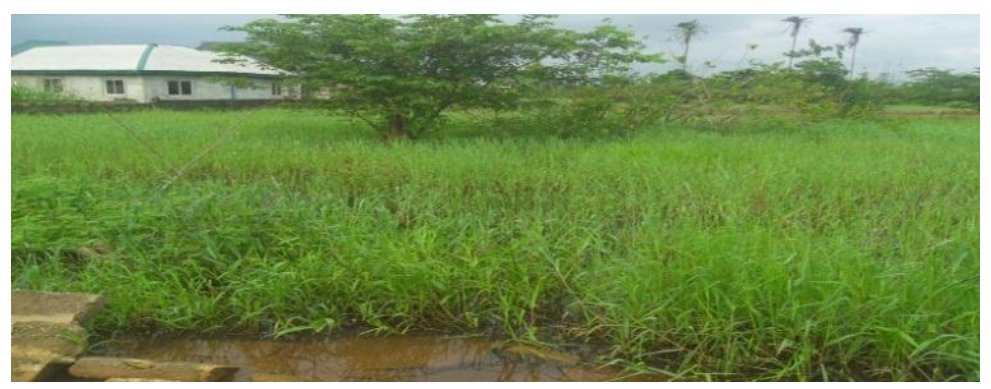

Plate 6: Freshwater Wetland being encroached in Mgbuoba /NTA road due to urbanization process

\subsection{Land Use Change Process/Distribution}

The urban land use maps delineated from change distribution data of 1984, 1999, 2003 and 2013 showed over the whole study period. The urban land use change of Port-Harcourt metropolis had changed dramatically during the period of 29 years. The data interpretation analysis/discussion is based on comparison between urban land use (Built-up area) and wetland ecosystem for different timelines, in the 29 year period. The spatial patterning of land use/land cover distribution area of 1984, 1999, 2003 and 2013 as derived from the image maps is presented in Table 3 and Figures 6- 13. The total area under study is 40066.59 (Ha).

Table 3: Size and Proportion of Land Cover Classes from 1984-2013

\begin{tabular}{|l|l|l|l|l|l|l|l|l|}
\hline CLASS NAME & 1984 Image area & $\mathbf{9}$ & 1999 Image (Ha) & $\mathbf{9}$ & 2003 image Area (Ha) & \% & 2013 Image Area(Ha) & \% \\
\hline Saltwater wetland & 6086.52 & 15.19 & 5190.23 & 12.95 & 5530.59 & 13.53 & 5411.79 \\
\hline Freshwater wetland & 12750.58 & 31.8 & 12886.20 & 32.16 & 10966.91 & 27.37 & 9747.28 & 13.50 \\
\hline Fallow land & 7777.8 & 19.4 & 4998.46 & 12.47 & 5387.26 & 13.44 & 5192.19 & 24.32 \\
\hline Built-up Area & 11100.8 & 27.7 & 14753.8 & 36.8 & 15915.6 & 39.72 & 19343.6 & 12.95 \\
\hline Water bodies & 2350.89 & 5.86 & 2237.9 & 5.58 & 2266.24 & 5.65 & 3111.61 & 48.27 \\
\hline Total & 40066.59 & 100 & 40066.59 & 100 & 40066.59 & 100 & 40066.59 & 7.76 \\
\hline
\end{tabular}

Table 3 shows that in 1984, built up area occupied the second highest classes with $27.7 \%$ (11100.8 Ha) of the total classes. This could be connected to low level of urban development, less pressure on wetlands, people having enough space to occupy and wetland being left alone. Both freshwater wetland and saltwater wetlands ecosystem occupied $46.99 \%$ ( $18837.1 \mathrm{Ha}$ ) of the total classes. This may be the result of wetland being in an undisturbed nature without any conversion or alteration for use.

In 1999, built up area (urban land use) rose to 36.8\% (14753.8 Ha) and maintained an increase in urban growth due to change from military to civilian rule (transitional period), constructions of many roads, empowerment by Government, and quest for white collar jobs. The two wetlands maintain a sharp reduction with a single digit of $45.11 \%$ 
(18076.43 Ha). The 1999 image scene shows a cloud cover during the period of image acquisition, and this led to an increase in figure instead of decrease. It remains the only single image that was clean and clear in the nineties.

As shown in Table 3, byin the year 2003, built up area (urban land use) occupied $39.72 \%$ (15915.6 Ha) of the total class with a high increase. The two wetlands (saltwater and freshwater wetland) sum up to atotal of $40 \%$ $(16497.5 \mathrm{Ha})$ which indicates that there is pressure on wetland use such as plant products harvested from fuel wood, urban agriculture, sand dredging, sanitation, water pollution and industrial activities from oil companies within the metropolis.

The year 2013 witnessed an expansion of cities in terms of developmental activities in all facets. Here, built up area recorded a two-fold increase in size. The pattern of land cover distribution in 2013 indicated that built-up areas were occupied by the development of greater Port-Harcourt city, as there was not enough space for development in the Port-Harcourt metropolis. People therefore tended to develop towards wetland ecosystem. Table 3 shows that both wetlands (saltwater and freshwater wetland) occupied $37.82 \%$ ( $15159.07 \mathrm{Ha}$ ). This is to say that there is a reduction in the size of both wetlands ecosystem due to rapid conversion of wetlands for housing development and excessive urban sprawl and its associated problems of inefficient use of land, urban space and the development of shanty towns/slums.

Other classes such as water bodies and fallow land in Table 3 can equally be reviewed. Water bodies maintained a constant size in volume over the years except in 2013, where it increased to $7.76 \%$ (3111.61 Ha). This sharp increase in the volume of water in 2013 was as a result of the 2012 flood menace in the country which resulted from most rivers, creeks, ponds and streams in the metropolis overflowing their banks and opening of water ways by the oil companies to ensure easy movement of their vessels. Water bodies occupied a total of $5.86 \%(2350.89 \mathrm{Ha})$ in 1984 , and experienced a slight decrease in size to $5.58 \%$ ( $2237.9 \mathrm{Ha}$ ) in 1999 and a little increase in size to $5.65 \%$ (2266.24 Ha) in 2003. Similarly, the result presented above indicates that in 1984, fallow land occupied $19.4 \%$ (7777.8Ha) of the land use area, and decreased to $12.47 \%$ (4998.46Ha) in the year 1999, with a slight increase to $13.44 \%$ (5387.26) in 2003, and then reduced to $12.95 \%$ ( $5192.19 \mathrm{Ha}$ ) in 2013.

\subsection{Result of Accuracy Assessment of Land use/Land Cover Map of the Study Area.}

A supervised classification of the satellite imagery was adopted to produce land use and land cover classes. The study made use of Maximum likelihood classification technique to perform its task, there by using all relevant spectral bands in each image. This is the most widely used classification algorithm $[24,25]$. To generate land cover classes, images of the study areas were taken in three stages: feature extraction, selection of training data (signatures), and selection of suitable classification approaches. The following five land use and land cover classes were identified and mapped: fallow land, saltwater wetland, built-up area, freshwater wetland and water bodies. After the classification, 20 sample points were generated to determine accuracy assessment, except in accuracy total report of 1999 where point generated was 25 points due to cloud cover.

In order to ascertain classification accuracy assessment, it is necessary to systematically compare two sources of information, the first one is pixels or polygon in remote sensing-derived classification map and the second one is ground reference test information. The relation between these two sets of data is usually summarized in an error matrix. The error matrix compares, on a category-by-category basis, the relation between known reference data and the corresponding result of an automated classification [26]. A researcher has proposed that two ways to evaluate and validate error matrix are descriptive statistical and multivariate analytical statistical methods [27].

Kappa Analysis is a multivariate analytical statistical method used and introduced to the remote sensing community in 1981 and was first published in remote sensing journal in 1983 [28,29]. It measures accuracy between the remote sensing-derived classification map (in this study LULC map of the study area) and the ground-truther data by the major diagonal of the error matrix, as well as the chance agreement, which is indicated by the row and column total referred to as marginal $[30,31]$.

According to a studies, Kappa value $>0.80$ represents a strong agreement or accuracy between the classification map and the ground reference, a Kappa value between 0.40 and 0.80 is considered moderate, and a Kappa value $<0.4$ represents a poor agreement.
Table 4: Accuracy Total Report (1984) of Port-Harcourt

\begin{tabular}{|l|c|c|c|c|c|}
\hline Class name & $\begin{array}{l}\text { Reference } \\
\text { totals }\end{array}$ & $\begin{array}{l}\text { Classified } \\
\text { totals }\end{array}$ & $\begin{array}{l}\text { Number } \\
\text { correct }\end{array}$ & $\begin{array}{l}\text { Producer's } \\
\text { accuracy } \\
\text { (\%) }\end{array}$ & $\begin{array}{l}\text { User's } \\
\text { accuracy } \\
\text { (\%) }\end{array}$ \\
\hline Fallow Land & 5 & 7 & 5 & $100 \%$ & $71.43 \%$ \\
\hline $\begin{array}{l}\text { Saltwater } \\
\text { wetland }\end{array}$ & 4 & 3 & 3 & $75 \%$ & $100 \%$ \\
\hline Built up area & 1 & 0 & 0 & $0 \%$ & $0 \%$ \\
\hline Fresh Water & 0 & 0 & 0 & $0 \%$ & $0 \%$ \\
\hline Water Bodies & 2 & 2 & 2 & 100.00 & 100.00 \\
\hline Total & 20 & 20 & 10 & & \\
\hline
\end{tabular}

Overall classification accuracy $=90.00 \%$

Kappa (K) statistics

Class name

Fallow Land

Saltwater wetland

kappa

Built up area

Freshwater wetland

0.6190

1.0000

0.0000

Water bodies $\quad 1.0000$

01.0000

Overall kappa statistic $=\quad 0.8596$

Table 5: Accuracy total report (1999) of Port Harcourt

\begin{tabular}{|l|c|c|c|c|c|}
\hline Class name & $\begin{array}{l}\text { Reference } \\
\text { totals }\end{array}$ & $\begin{array}{l}\text { Classified } \\
\text { totals }\end{array}$ & $\begin{array}{l}\text { Number } \\
\text { correct }\end{array}$ & $\begin{array}{l}\text { Producer's } \\
\text { accuracy } \\
\text { (\%) }\end{array}$ & $\begin{array}{l}\text { User's } \\
\text { accuracy } \\
\text { (\%) }\end{array}$ \\
\hline Fallow land & 2 & 0 & 0 & - & - \\
\hline $\begin{array}{l}\text { Saltwater } \\
\text { wetland }\end{array}$ & 2 & 2 & 2 & $100.00 \%$ & $100.00 \%$ \\
\hline Built up area & 6 & 5 & 5 & $83.33 \%$ & $100.00 \%$ \\
\hline $\begin{array}{l}\text { Freshwater } \\
\text { wetland }\end{array}$ & 5 & 8 & 5 & $100.00 \%$ & $62.50 \%$ \\
\hline Water bodies & 0 & 0 & 0 & - & - \\
\hline Total & 25 & 25 & 22 & & \\
\hline
\end{tabular}

Overall classification Accuracy $=88.00 \%$

Kappa (k) Statistics

Class name kappa

Fallow land $\quad 0.0000$

Saltwater wetland $\quad 1.0000$

Built up Area $\quad 1.0000$

Freshwater wetland $\quad 0.5313$

Water bodies 0.0000

Overall kappa statistics $=\quad 0.8337$

Table 6: Accuracy total report (2003) of Port Harcourt

\begin{tabular}{|l|c|c|c|c|l|}
\hline Class name & $\begin{array}{l}\text { Reference } \\
\text { totals }\end{array}$ & $\begin{array}{l}\text { Classified } \\
\text { totals }\end{array}$ & $\begin{array}{l}\text { Number } \\
\text { correct }\end{array}$ & $\begin{array}{l}\text { Producer's } \\
\text { accuracy } \\
\text { (\%) }\end{array}$ & $\begin{array}{l}\text { User's } \\
\text { accuracy } \\
\text { (\%) }\end{array}$ \\
\hline Fallow land & 2 & 2 & 2 & $100 \%$ & $100 \%$ \\
\hline $\begin{array}{l}\text { Saltwater } \\
\text { wetland }\end{array}$ & 3 & 3 & 3 & $100.00 \%$ & $100.00 \%$ \\
\hline Built up area & 5 & 5 & 5 & $100.00 \%$ & $100.00 \%$ \\
\hline $\begin{array}{l}\text { Freshwater } \\
\text { wetland }\end{array}$ & 0 & 0 & 0 & - & - \\
\hline Water bodies & 1 & 1 & 1 & $100.00 \%$ & $100.00 \%$ \\
\hline Total & 20 & 20 & 20 & & \\
\hline
\end{tabular}

Overall classification Accuracy $=100 \%$

Kappa (k) Statistics

Class name kappa

Fallow land $\quad 1.0000$

Saltwater wetland $\quad 1.0000$

Built up Area $\quad 1.0000$

Freshwater wetland $\quad 1.0000$

Water bodies $\quad 1.0000$

Overall kappa statistics $=\quad 1.0000$

Table 7: Accuracy total report (2013) of Port Harcourt

\begin{tabular}{|l|c|c|c|c|c|}
\hline Class name & $\begin{array}{l}\text { Reference } \\
\text { totals }\end{array}$ & $\begin{array}{l}\text { Classified } \\
\text { totals }\end{array}$ & $\begin{array}{l}\text { Number } \\
\text { correct }\end{array}$ & $\begin{array}{l}\text { Producer's } \\
\text { accuracy } \\
\text { (\%) }\end{array}$ & $\begin{array}{l}\text { User's } \\
\text { accuracy } \\
\text { (\%) }\end{array}$ \\
\hline Fallow land & 0 & 0 & 0 & - & - \\
\hline
\end{tabular}




\begin{tabular}{|l|c|c|c|c|c|}
\hline $\begin{array}{l}\text { Saltwater } \\
\text { wetland }\end{array}$ & 2 & 2 & 2 & $100.00 \%$ & $100.00 \%$ \\
\hline Built up area & 5 & 5 & 5 & $100.00 \%$ & $100.00 \%$ \\
\hline $\begin{array}{l}\text { Freshwater } \\
\text { wetland }\end{array}$ & 2 & 2 & 2 & $100.00 \%$ & $100.00 \%$ \\
\hline Water bodies & 1 & 1 & 1 & $100.00 \%$ & $100.00 \%$ \\
\hline Total & 20 & 20 & 20 & & \\
\hline
\end{tabular}

Overall Classification Accuracy $=100.00 \%$

Kappa (k) Statistics

Class name

Fallow land

Saltwater wetland

kappa

Built up Area

Freshwater wetland

0.0000

1.0000

1.0000

1.0000

Water bodies

1.0000

Overall kappa Statistics =

1.0000

Analysis based on overall accuracy assessment in Tables 4, 5, 6 and 7 showed that the 1984 classification based on the assessed Landsat TM Map was $90.00 \%$, with a kappa coefficient statistic of $0.85 \%$, while the overall accuracies for 1999 image classification based on Landsat ETM was $88.00 \%$ with a kappa coefficient statistic of 0.8337 ; the 2003 image scene classification accuracy based on Landsat ETM was $100.00 \%$ with a kappa coefficient statistic of 1.0000 respectively. The 2013 image classification accuracy based on Landsat7 ETM was $100.00 \%$ with kappa overall coefficient statistics of 1.0000 . The minimum standards as stipulated above meet USGS classification scheme.

\section{CONCLUSION}

Since it is impossible to avoid change in time and space there is a crucial need for planning in the Port Harcourt metropolis. This study revealed a very alarming rate of wetland reduction and expansion of built-up area. Sound planning is needed to protect and preserve wetland ecosystem. If no adequate measures are taken, wetland resources in the Port Harcourt Metropolis may grossly become extinct. This is because of the following:

- Wetlands and fallow land experienced both absolute and relative losses between 1984 and 1999.

- Within 1999-2013, built-up area experienced a positive increase while freshwater wetland and water bodies came up with negative reduction in their magnitude.

- Within 2003-2013, freshwater wetland hit a negative change in reduction and saltwater wetland in this period made the lowest conversion. Built-up areas and water bodies exhibited positive change in the study.

- $\quad$ Drivers of the land use and land cover change in Port-Harcourt metropolis include demographic factors, urbanization, infrastructural development and oil and gas activity.

It is recommended that:

Efforts should be made to increase knowledge, sensitization, consultation, stakeholder's participation and awareness on the wetlands values and wise use economy through dissemination of information, using appropriate techniques and training of adequate staff.

There is need for sound wetland policies, laws and legislation for sustainable use, management and control in conservation of wetland.

There is need for improvement of institutional arrangement so that wetland policies can be fully integrated into the urban planning process across all departments.

\section{REFERENCES}

[1] Ramsar Iran. 1971. Ramsar Convention on Wetland: Ramsar Handbooks for The Wise Use of Wetlands, 4th Edition.

[2] Ramsar Convention Secretariat. 2007. Wise Use of Wetlands: A Conceptual Framework For The Wise Use of Wetlands. Ramsar Handbooks for The Wise Use Of Wetlands. $3^{\text {rd }}$ Ed. Gland (Switzerland): Rcs.
[3] Barbier, E.B., Acreman, M., Knowler. D. 1997. Economic Valuation of Wetlands: A Guide For Policy Makers and Planners. Gland (Switzerlands): Ramsar Convention Bureau.

[4] Nwankwoala, H.O. 2011. An Integrated Approach to Sustainable Development and Management of Groundwater Resources of Nigeria. Journal of Geology and Mining Research, 3 (5), 123-130.

[5] Wali, E. 2015. Urbanization and Loss of Wetlands in Port-Harcourt Metropolis, Nigeria. An Unpublished M.Sc. Thesis; Department of Geography University of Nigeria, Nsukka.

[6] Mathews, G.V.T. 1993. The Ramsar Convention on Wetlands: Its History and Development. In Luthi E, Ramsar, Editors. Gland (Switzerland): Ramsar Convention Bureau.

[7] Tunner, R.K., Van Den Bergh, J.C.J.M., Soderzvist, T., Barendregt, A., Van Der Staaten J., Maltby, E., Van Ler Land, E. C. 2000. Ecological -Economic Analysis Of Wetlands:Scientific Integration For Management And Policy. Ecological Economics, 35, 7-23.

[8] Ramsar Convention. 2010. Accessible At Http://Www.Ransar.Org/Cda/Ransar/20/04/2011.

[9] Adedeji, D., Eziyi, O. I. 2010. Urban Environmental Problems in Nigeria: Implication For Sustainable Development. Journal of Sustainable Development in Africa, 12 (7), 124-145.

[10] Williams, M. 1990. Protection and Retrospection In Wetlands: A Threatened Landscape. Black Well. Oxford.

[11] Nwankwoala, H.O. 2012. Case Studies on Coastal Wetlands and Water Resources In Nigeria. European Journal of Sustainable Development, 12 113-126.

[12] Zalids, G.C., Martzave, Las, A.L., Gourvelon, E. 1997. Environmental Impacts On Greek Wetlands, 17, 339-345.

[13] Ringrose, S., Matheson, W., Boyle, T. 1988. Differentiation of Ecological Zones in The Okavango Delta Bostwana, By Classification and Contextual Analysis of Landsat Mss Data. Photogram. Eng. Remote Sens. 54, 601-608.

[14] Garakis, A., Kalburtji, K. 1998. Agricultural Activities Affecting the Functions and Values of Ramsar Wetland Sites of Greece Agric Ecosystem. Environment, 70, 119-128.

[15] Chopra, R., Verma, V.K., Harma, P.K. 2001. Mapping, Monitoring and Conservation of Harike Wetland Ecosystem. Punjab India, Through Remote Sensing: Inter. Journal of Remote Sensing, 1, 89-98

[16] Okoye, T.O. 1975. Port-Harcourt In Ofomata, G. E. K. (Ed). Nigeria In Maps: Eastern States. Ethiope, Benin City, 92-93.

[17] Oyegun, C.U., Adeyemo, A. 1999. Port-Harcourt Region (Ed). Paragraphics Port Harcourt, 1-12.

[18] Alagoa, E.J., Derefaka, A.A. 2002. The Land and People of Rivers State: Eastern Niger Delta. Onyoma Research Publication.

[19] Ayoade, J.O. 1993. The Introductory Climatology for The Tropics Spectrum Books Ltd., Ibadan, Nigeria.

[20] Umeuduji, J. E., Aiseuebeogun, A. 1999. Relief and Drainage, In Oyegun C. U. And Adeyemo. A. (Eds). Land and People of Rivers State. River Side Communication, Port- Harcourt, 24-30.

[21] Anderson. 1976. A Land Use and Land Cover Classification System for Use with Remote Sensor Data. Geological Survey Professional Paper No. 964, Us. Government Printing Office, Washington, D.C. P. 28

[22] Samuel, K.A. 2006. Managing Wetlands in Accra, Ghana. African Regional Workshop Cities, Ecosystems and Biodiversity Nairobi, 21 September 2006. Side Event at The Africities Summit (18-24 September 2006).

[23] Agbi, J.A., Abang, S.O., Animashaun, A.I. 1995. Nigerian Environment. Nigerian Conservation, Module 2. Mac Millian Nigerian, Lagos. 
[24] Mamandhar, R., Odeh, I.O.A., Ancev, T. 2009. Improving the Accuracy Of Land Use And Land Cover Classification Of Land Sat Data Using Post Classification Enhancement. Remote Sensing, 1 (3), 330-344.

[25] Eric, K.F., Adubofour, F. 2012. Analysis of Forest Cover Change Detection in Owabi Forest Reserve Kumasi, Ghana. International Journal of Remote Sensing Applications, 2 (4).

[26] Lillesland, M.T., Kiefer, W.R., Dupman, W.J. 2004. Remote Sensing and Image Interpretation. 5th Edition, John Wiley And Son, Inc., New York.

[27] Jensen, J.R. 2005. Introductory Digital Image Processing: A Remote Sensing Perspectives. 3rd Edition Prentice Hall Series in Geographic Information Science.
[28] Congalton, R. 1981. A Review of Assessing the Accuracy of Classification of Remotely Sensed Data. Remote Sensing of Environment, 37 (1), 35-46.

[29] Congalton, R.G., Oderwald, R. G., Mead, R.A. 1983. Assessing Land Sat Classification Accuracy Using Discrete Multivariate Analysis Statistical Techniques, Photogrammetric Engineering and Remote Sensing 59, 529535.

[30] Rosenfield, G., Fitzpatrick-Lines, K.A. 1986. Coefficient of Agreement as A Measure of Thematic Classification Accuracy. Photogrammetric Engineering and Remote Sensing, 52 (2), 223-227.

[31] Congalton, R.G. 1996. Accuracy Assessment: A Critical Component of Land Cover Mapping. Gap Analysis. American Society for Photogrammetric and Remote Sensing, 119-131. 